\title{
The current state of application of biological plant protection agents in agrocnosis of Ukraine
}

\author{
Tkalenko H. ${ }^{1}$, Borzykh O. ${ }^{2}$, Ihnat V. ${ }^{3}$ \\ Institute of Plant Protection of NAAS \\ 33 Vasylkivska Str., Kyiv, 03022, Ukraine \\ e-mail: microbiometod@ukr.net \\ ORCID: ${ }^{1} 0000-0001-9448-6600,{ }^{2} 0000-0002-9802-5622,{ }^{3} 0000-0002-1992-3097$
}

Goal. To analyze the long-term data on the development and application of biological plant protection products in Ukraine. Methods. Microbiological, biochemical, entomological, field, mathematical-statistical, and information-analytical. Results. It is established that in Ukraine for the last 20 years the areas of cultivated agricultural lands treated with biological means of plant protection against pests decreased from $8.5 \%(2000)$ to $3.6 \%(2019)$, and in 2006 the share of the areas treated with bioresources was the lowest $(2.9 \%)$. Most biological drugs are used against mouse-like animals, gnawing and leaf-eating moths, stem butterfly and pest complex in vegetable and grain agrocnosis, and in orchards. Scientific developments on the biological method of plant protection are given. An ecologically safe system of protection of vegetable crops of open and closed soil is developed and tested. The search for highly effective strains of microorganisms for the creation and development of new biological preparations is carried out. Methods of step-by-step selection with the determination of productive monoisolates to obtain production strains of entomopathogens have been studied. The deep technology of low-tonnage production of the biological product Trikhodermin- $R$ for the conditions of bio laboratories of Ukraine has been improved. Conclusions. It is established that the cultivated areas treated with biological plant protection products decreased every year and in 2019 amounted to 1.8 million hectares out of 49.8 million hectares of all cultivated areas. The Institute of plant protection of NAAS has developed an environmentally friendly system of protection of vegetable crops in open and closed soil against pests and created a collection of highly active and productive strains of entomopathogens, microorganismsantagonists, predatory nematophage fungi - producers of biological drugs, plant protection products in Ukraine.

Key words: pesticides, pests, pathogens, entomophage.

DOI: https://doi.org/10.31073/agrovisnyk202012-03

The problem of maintaining homeostasis of the environment poses a challenge to science and practice to find safer ways to control pests and pathogens of crops.

Today in Ukraine there is a need for biologization of protective measures, which is caused not only by environmental and social, but also economic problems. Based on this, one of the main elements of modern technologies of phytosanitary optimization of agroecosystems and obtaining environmentally friendly products is the use of biological means of protection.

According to the Council of Europe Resolution № 834/2007 of 28.06.2007, the biological method is the main strategic ecologically safe measure of pest control in crops with organic cultivation.

The essence of the biological method of plant protection is to use against pests their natural enemies (predators, parasites) and products of their activities, obtaining high quality environmentally friendly products while maintaining the biological diversity of biocenoses. Biological plant protection is the regulation of the number (biological control) of harmful organisms [1].

Biological plant protection products against pests and diseases are an important, integral part of the integrated protection system in modern crop production, and in some cases, in particular indoors, as one of the main means of protecting vegetables during the growing season and as the only means of controlling phytophagous and phytopathogenic. during the harvesting of vegetables, because according to the Law of Ukraine "On Pesticides and Agrochemicals" (Article 13), the use of chemicals in greenhouses is limited.

The development of the agricultural sector in recent decades is characterized by strict concentration and specialization of agricultural production, cultivation of intensive varieties and active use of powerful man-made factors: fertilizers, machinery, plant protection products. The intensification of agriculture, the introduction of crop rotation with short rotation and even the transition in some farms to monoculture, have led to a significant reduction in biodiversity not only in agrocenoses, but also in other biocenoses of the agro-landscape. As a result, there was a radical violation of natural regulatory mechanisms in ecosystems, which causes serious negative consequences of an ecological nature. Modern crop production is characterized by extremely low stability of phytosanitary conditions (outbreaks of mass reproduction of pests, epiphytosis of diseases, widespread weeds) and significant progressive deterioration [2]. 
Based on this, it is necessary to solve two interrelated tasks: to increase production and reduce the pesticide load on agrocenoses. Radical changes in improving plant protection against pests should be based on a fundamentally new strategy aimed at the overall phytosanitary optimization of agrocenoses. The modern concept of plant protection involves the abandonment of total destruction of pests and the gradual transition to the creation of phytosanitary stable agroecosystems, which should operate a mechanism of self-regulation and management of pests [3].

Currently, economic and environmental problems require significant changes in the developed technologies in the direction of their biologization and resource conservation while ensuring high profitability of agricultural production. This opens the way to the development of new directions in the cultivation of crops with the maximum use of biological means of protection.

Purpose To analyze long-term data on the development and application of biological protection in Ukraine.

Materials and research methods. The research was conducted during 2000-2019 in the laboratory of the microbiological method of plant protection IZR and in farms of different forms of ownership, according to the methods generally accepted in microbiology and entomology [4-6].

The information-analytical method was used to analyze the database of the Department of Phytosanitary Safety, Seed Control and Nursery Control of the State Food and Consumer Service of Ukraine.

Research results. By the mid-nineties of the twentieth century our state took the leading place among the countries of the former Union in the use of biological plant protection products. The biological method was applied on an area of about 5 million hectares, 268 biofactories and biolaboratories were working at full capacity. But, in the 90's due to economic problems, the production of biological drugs was significantly reduced.

According to modern technologies of growing crops, according to the State Food and Consumer Service [7] in Ukraine as of 1.01.2000, the average annual scale of work to protect work in farms of various forms of ownership was 12.9 million hectares. The use of biological agents was carried out on an area of 1.1 million hectares, which is $8.5 \%$.

The total amount of treatments against pests in subsequent years increased, and in 2004 reached 20.5 million hectares. On the contrary, the share of biological protection works decreased to $4.4 \%$ in 2001-2004.

Improvements were noted in 2005, as the share of biological agents in agrocenoses was $8.2 \%$ (1.9 million hectares).

During 2006-2010, the area of treatments against pests and diseases using protective measures increased by $39.7 \%$, but the share of the biological method in 2006 was $0.7(2.9 \%)$, in $2007-1.1(3.9 \%)$, in 2008 and 2009 - respectively 1.2 and 1.6 million hectares (3.4 and 4.5\%). In 2010, the amount of biological agents increased to 2.1 million hectares $(5.3 \%)$.

Compared to previous years, in 2011 the scale of protective measures increased significantly and reached 45.9 million hectares, while the volume of biological treatments increased to 2.3 million hectares.

A similar situation was observed in the following years. Thus, works on the application of the biological method of plant protection in 2012-2014 were carried out on an area of 2.0-2.3 million hectares. In 2015, the volume of applications of biological drugs and entomophages amounted to $5.0 \%$ of all measures.

Since 2016, there has been a tendency to increase the cultivated area with pesticides, but the use of the biological method is decreasing every year. Thus, in 2016, protective measures were carried out on an area of 45.2 million hectares, of which biological - 2.1 million hectares (4.6\%). In 2017, the amount of treatments against pests and diseases of crops amounted to 46.8 million hectares, of which biological 2.1 million hectares $(4.5 \%)$.

In 2018-2019, measures were taken to protect agricultural lands from pests on areas of about 50 million hectares, and the share of the application of the biological method of plant protection decreased from $4.1 \%$ (2018) to 3.6\% (2019).

It should be noted that the dynamics and structure of the biological method of plant protection against pests and diseases on different crops differ significantly. Thus, the largest volumes of biological preparations are carried out against murine rodents, gnawing and leaf-eating moths, stem butterfly and pest complex in vegetable and grain agrocenoses and in orchards.

By 2009, the application of biological drugs against cute rodents reached $40.1-77.8 \%$ of all areas treated with biological agents. During the period 2010-2019, the share of the biological method of protection against this pest decreased from $25.1 \%$ to $8.1 \%$.

The biological method of protecting crops from stem butterflies is widely used. In recent years, there has been a significant increase in the use of biological measures against this dangerous pest. So, from 100 thousand hectares of the areas processed by biological means in 2000 to 917 thousand hectares in 2014. In 2020, it is planned to carry out biological measures against the stem butterfly on 700 thousand hectares.

There is a tendency to increase the volume of treatments with biological agents against pests and diseases on vegetable crops. If in 2000-2008 biological agents were used on areas of 2-3 thousand ha, 
in 2009-2014 the volumes of biological treatments increased to 34 thousand ha, and in 2015-2017 increased by $23.5 \%$ and amounted to about 80.0 thousand hectares.

Thus, the analysis of data from the Department of Phytosanitary Safety, Seed and Nursery Control of the State Food and Consumer Service of Ukraine on the use of biological crop protection products for 2000-2019 showed that the share of cultivated areas with biological pesticides in Ukraine is from 2.9 up to $8.5 \%$ of all cultivated areas.

Thus, the amount of treatment of agricultural land with biological agents is insignificant, as the use of chemicals predominates, which in turn has a negative effect on agrocenoses, as it leads to soil and food contamination.

During the last decades in Ukraine a large number of biological preparations based on different types of bacteria have been created to increase yields, assimilation, binding and fixation of atmospheric nitrogen, mobilization of hard-to-reach phosphorus from the soil [9].

Currently, there are about 40 biolaboratories in Ukraine, which develop biological plant protection products. The biological method acquires special significance in open and closed soil vegetable growing, where the products are consumed fresh during the whole vegetation period and chemical treatments are undesirable. Its potential is also extremely high on fruit and berry crops, during the cultivation of which numerous chemical treatments are often carried out.

The range of biological agents is represented mainly (by $70 \%$ ) by microbiological drugs, the share of entomophagous in the open ground is about $30 \%$, where mainly trichogram (1-2 species) is used, and in the closed ground amblyceus, phytoseiulus, encarsia, macrolofus, aphidium, galicia [10].

To the "List of pesticides and agrochemicals... in Ukraine for 2018." [11] included 123 biological products. Of these, 8 drugs are registered to protect crops from diseases, 9 - from pests, which is respectively 6.5 and $7.3 \%$ of the total number of registered and approved for use biological drugs.

The largest share in the structure of biological means of protection are biological products to improve nutrition and increase crop yields - $31.7 \%$. The share of biologicals for the absorption of atmospheric nitrogen is $24.4 \%$ ( 30 drugs), for the mobilization of hard-to-reach phosphorus - $2.4 \%$ ( 3 drugs).

Thus, one of the main factors influencing the expansion of the use of biological products in agrocenoses is their production, and one of the requirements for the organization of any industrial production, including microbiological, is their environmental safety, in particular the absence of polluting industrial waste water arteries and soils. Therefore, the task of developing environmentally friendly lowtonnage technologies for the production of biological products is one of the most important.

It is in this direction that long-term research is conducted at the Institute of Plant Protection of NAAS. Scientists of the institute have improved the existing and developed new technologies for the development of biological drugs, based on highly productive strains of entomopathogens, antagonist fungi and predatory nematophage fungi.

The search for highly effective strains of microorganisms for the creation and development of new biological drugs. There were 67 strains of the fungus Beauveria bassiana, 21 - Metarhizium anisopliae, 6 - Paecilomyces farinosus, 1 - Aspergillus, 47 - carnivorous nematophage fungi Arthrobotrys spp. For practical use as producers of biological products, new strains of the fungus Beauveria (K-1, K-7, P-1, 71661), Metarhizium (01-115 and 04-106) were selected; Paecilomyces ( $\mathrm{P}-14, \mathrm{P}-15, \mathrm{P}-16)$, Arthrobotrys: A. musifornis 131, A. oligospora 9 and A. arthrobotryoides 21, which exceed the basic parameters of reference strains and are promising for introduction into agrocenoses for bioregulation of pest populations [12].

A model for obtaining production strains of entomopathogenic fungi-producers of biological products has been developed, which makes it possible to select active clones that are stable according to the main criteria - entomocidity, manufacturability, ability to exist in agrobiocenoses [13].

New highly active strains of the fungi Beauveria bassiana 71661 (IMBF-100051) and Trichoderma lignorum № 23 (IMBF-100062) were obtained. A unified nutrient medium for the production of biologicals Boverin- $R$ and Trichodermin- $R$ has been developed. Technological parameters for Trichodermin- $P$ were optimized: temperatures $+24-26{ }^{\circ} \mathrm{C}$ - within 72 hours, $28-30{ }^{\circ} \mathrm{C}-48-60$ hours, $\mathrm{pH} 4.0-4.5$, amount of seed 2 million spores per use surface culture, aeration intensity $0.7-0.9 \mathrm{~g} \mathrm{O}_{2} / \mathrm{h}$. [14].

An energy- and labor-saving technology for the production of Trichodermin- $R$ biological product has been developed, which has advantages over the existing one: the cost of the environment, duration of technological process, labor costs are reduced by $2.5-3$ times, production waste is eliminated, sanitary and hygienic working conditions are improved [15].

It has been studied that biopreparations based on a fungus-antagonist of the genus Trichoderma and non-spore bacteria of the genus Pseudomonas provide high efficiency against diseases of vegetable crops in open and closed soil [16].

At their complex application (soaking of seeds in $0,5 \%$ solution, four drop irrigation during vegetation by $0,1 \%$ suspension) on cucumbers in greenhouses in autumn-winter and winter-spring crop rotations the defeat of cucumbers by root rot decreases, by 75,5 on $6 \%$, the yield increases from 5.5 to $10.5 \mathrm{~kg} / \mathrm{m} 2$ [17].

In the future, the use of biological means of protection indoors can reach up to $90 \%$, and in the open ground on vegetables, potatoes, industrial crops, in gardens up to $40-50 \%$. The introduction of the 
developed ecologically safe systems of protection of vegetable crops of open and closed soil will improve the phytosanitary condition of vegetable agrocenoses, will allow to increase the share of biological agents in integrated systems to $65-80 \%$, to reduce pesticide load by $2.0-2.5$ times, to reduce crop losses and get quality vegetable products.

Thus, the results of our developments in the development and application of biological plant protection products, which are aimed at maintaining biocoenotic balance in agrocenoses, should be used in integrated pest management systems.

It is also necessary to conduct systematic research on the development and implementation in research and production conditions of zonal technologies of complex biologization of plant protection, to create on the basis of biolaboratories, mainly of regional importance, specialized production of biological plant protection products for a wide range of uses.

\section{Conclusions}

It is established that the share of cultivated areas by biological means of protection of agricultural crops from pests in Ukraine for the last 20 years is $2.9-8.5 \%$ of all cultivated areas.

Introduction of biological preparations on the basis of new strains of microorganisms and their introduction into agrocenoses will allow to improve phytosanitary condition, at the expense of essential reduction of pesticidal loading and increase of useful microflora, to increase profitability of cultivation of vegetable production in the closed ground at the expense, to obtain high-quality environmentally friendly products that are competitive in the Ukrainian and European markets.

\section{References}

1. Brovdi, V.M., Hulyi, V.V., \& Fedorenko, V.P (2004). Biolohichnykh zakhyst ros/yn [Biological plant protection]. Kyiv: Svit. [in Ukrainian].

2. Fedorenko, V.P., Tkalenko, A.N., \& Konverskaya, V.P. (2006). Ispolzovanie biosredstv V sovremennykh tekhnologiyakh fitosanitarnoy optimizatsii agroekosistem [The use of biological agents in modern technologies for phytosanitary optimization of agroecosystems]. Biological method sinintegrated Plant Protection and Production. Conferenze, Poznan, Poland. P. 46. [in Poland].

3. Tkalenko, H.M. (2018). Metodychni rekomendatsii iz zastosuvannia bezpestytsydnoi tekhnolohii zakhystu ovochevykh kultur vid khvorob i shkidnykiv pry vyrobnytstvi orhanichnoi produktsii. [Methodical recommendations on the use of safety technology for the protection of vegetable crops from diseases and pests in the production of organic products]. Kyiv. [in Ukrainian].

4. Dospekhov B.A. (1985). Metodyka polevoho opyta [Field experiment technigue]. Moskva: Kolos. [in Russia].

5. Omeliuta, V.P., Hryhorovych, I.V., Chaban, V.S. et al. (1986). Oblik shkidnykiv i khvorob silskohospodarskykh kultur. [Accounting for pests and diseases of crops]. Kyiv: Urozhai. [in Ukrainian].

6. Trybeli, S.O. (Ed). (2001). Metodyky vyprobuvannia i zastosuvannia pestytsydiv. [Methods of testing and application of pesticides]. Kyiv: Svit. [in Ukrainian].

7. Prohnoz fitosanitarnoho stanu ahrotsenoziv Ukrainy ta rekomendatsii shchodo zakhystu roslyn. [Forecast of phytosanitary condition of agrocenoses of Ukraine and recommendations on plant protection]. URL: https://www. dpss.gov.ua/fitosanitariya-kontrol-u-sferi-nasinnictva-ta-rozsadnictva [in Ukrainian].

8. Tkalenko, G.M. (2015). Bioligical control of diseases and pests of vegetable crops in greenhouse. Microbiological aspects of optimization of the production Process of cultured crops: proceedings of the International Scientific and Practical. Internet conference. Chernihiv - Nizhyn. (pp. 57-59). [in Ukrainian].

9. Belogubova, E.N. (A.Y. Pashkovskyi (Ed.)). (2006). Sovremennoe ovoshchevodstvo zakrytogo $i$ otkrytogo grunta: ucheb. posobie dlya agr. ucheb. zavedenie I-IV urovney akkreditatsiy po spets. 1310 "Agronomiya». [Modern indoor and outdoor vegetable growing: textbook. manual for agr. study. establishment of I-IV levels of accreditation for special 1310 "Agronomy"]. Kiev: Kiev pravda. [in Ukrainian].

10. Yarovyi, H.I. (Ed). (2006). Dovidnyk z pytan zakhystu ovochevykh i bashtannykh roslyn vid shkidnykiv, khvorob ta burianiv. [Handbook on the protection of vegetable and melon plants from pests, diseases and weeds]. Kharkiv. [in Ukrainian].

11. Perelik pestytsydiv i ahrokhimikativ, dozvolenykh do vykorystannia $v$ Ukraini. (2018). [List of pesticides and agrochemicals approved for use in Ukraine]. Kyiv: Yunivest Media. [in Ukrainian].

12. Tkalenko, A.N., \& Goral, S.V. (2007). Poisk vysokovirulentnykh shtammov entomopatogenov v agrotsenozakh Ukrainy. [Search for highly virulent strains of entomopathogens in agrocenoses of Ukraine]. Information bulletin EPRS IOBC. Sankt-Peterburg, 8, 230-232. [in Russian].

13. Tkalenko, H.M., \& Horal, S.V. (2013). Optymizatsiia parametriv hlybynnoho kultyvuvannia hryba rodu Trichoderma. [Optimization of parameters of deep cultivation of a fungus of the genus Trichoderma]. Plant protection and quarantine: interdepartmental thematic scientific collection, 59, 311-319. [in Ukrainian]. 
14. Tkalenko, H.M. et al. (2012). Zastosuvannia biolohichnoho preparatu Trykhodermin-R dlia zakhystu ovochevykh kultur zakrytoho i vidkrytoho gruntu vid khvorob: rekomendatsii. [The use of the biological drug Trichodermin- $R$ to protect indoor and outdoor vegetable crops from disease: recommendations]. Kyiv. [in Ukrainian].

15. Horal, S.V., \& Tkalenko, H.M. (2012). Rekomendatsii z vyrobnytstva biolohichnoho preparatu Trykhodermin-R za hlybynnoiu tekhnolohiieiu v umovakh vyrobnychykh biolaboratorii. [Recommendations for the production of biological product Trichodermin- $R$ in depth technology in the production of biolaboratories]. Kyiv: Kolobih. [in Ukrainian].

16. Tkalenko, A.N. (2013). Ispolzovanie biologicheskikh preparatov v zashchite kapusty belokochannoy ot bakteriozov. [The use of biological preparations in the protection of white cabbage from bacteriosis]. Plant protection: collection of scientific papers. Minsk, 37, 270-276. [in Belarusian].

17. Sergienko, V.G., Tkalenko, A.N., Titova, L.V. (2010). Ispolzovanie biopreparatov dlya zashchity ovoshchnykh kultur ot bolezney. [The use of biological products to protect vegetable crops from diseases]. Plant protection and quarantine. Sankt-Peterburg, 7, 28-30. [in Russian]. 